\title{
3' Untranslated Region Mutation
}

National Cancer Institute

\section{Source}

National Cancer Institute. 3' Untranslated Region Mutation. NCI Thesaurus. Code C63433.

Any mutation in a gene occurring in the 3 ' end which contains sequences which may regulate the transcription or translation of the message. 3' UTR mutations are found only outside of open reading frames. 